\title{
EVALUATION OF THE STATE OF IMPLEMENTATION OF THE EUROPEAN STRUCTURAL AND INVESTMENT FUNDS: CASE STUDY OF THE SLOVAK REPUBLIC
}

Boris MUCHA, PhD

Comenius University in Bratislava, Faculty of Management, Slovakia

mucha8@uniba.sk

\begin{abstract}
Today, Slovak Republic already has 20 years of experience in the management, implementation and control of European funds, which should be used in the next programming period 2021-2027, which represents cohesion policy post-2020. Preparedness and flexibility will be a prerequisite for a successful implementation of this programming period. In the context of expected changes and new rules, it is essential that the responsible national authorities are able to prepare not only the new Partnership Agreement and documents at strategic level in a timely manner, but also the operational programmes themselves, through which European Union policies will be implemented. In view of the above, the aim of the paper is to evaluate Slovakia's state of preparedness for the next programming period 2021 - 2027 and propose recommendations to improve the management, implementation and control of the European Structural and Investment Funds. Research will mainly use a comparative analysis of selected financial indicators for the implementation of the completed programming period 2007-2013 and the ongoing 2014-2020 programming period. Theoretical knowledge and own practical experience in implementing and auditing European funds will also be used to achieve the objective.
\end{abstract}

Keywords: European funds, management, implementation, programming period, financial indicator.

\section{Introduction}

The European Union is based on its individual regions, politically, economically and socially. The European Union's cohesion policy is therefore essential for the success of the Member States and of the Europe as a whole. EU transfers have improved welfare. Further welfare can be reached by reallocating funds across regions without increasing the budget (Blouri and Ehrlich, 2020).

Slovak Republic had already gained experience of implementing European funds before its accession to the European Union, when it used so-called pre-accession funds. Their purpose was 
to increase Slovakia's readiness to join the Union. Pre-accession funds comprised the PHARE, ISPA and SAPARD programmes and their financial management was implemented by the National Fund. Since then, Slovakia has been implementing European funds continuously until now.

The 2007-2013 programming periodwas the first to be used by Slovakia throughout its duration. During this programming period, the European Union's cohesion policy focused on 3 main objectives, namely Convergence, Regional Competitiveness and Employment and European Territorial Cooperation. The first two were part of the National Strategic Reference Framework, which comprised a total of 11 operational programmes focusing on diverse areas of support, e.g. health, transport, computerisation of society, education and research and development (Mura and Vlacseková, 2018). Under the European Territorial Cooperation objective, cross-border cooperation programmes have been implemented with Austria, Hungary, Czechia or Poland. Neither the Rural Development Programme implemented under the European Agricultural Fund for Rural Development nor the Fisheries Operational Programme implemented under the European Maritime and Fisheries Fund can be omitted.

The current programming period 2014-2020 has a number of similar features with the previous period. Cohesion policy for this period represents 11 thematic objectives to boost growth, including support for research, development and innovation, increasing the competitiveness of small and medium-sized enterprises, supporting the transition to a low-carbon economy, supporting climate change adaptation, promoting sustainable transport, promoting labour mobility, combating poverty and improving the efficiency of public administration (European Commission, 2014). The original three objectives of the previous period have been replaced by two, "Investment for growth and jobs" and "European territorial cooperation" (Kubincová et al., 2018). At the same time, the number of programmes has been reduced. While a total of 11 programmes were implemented under the Convergence and Regional competitiveness and employment objectives in the 2007-2013 programming period, 7 programmes are implemented under the Investment for growth and jobs goal in the current period (Peráček, 2020). There have been no major changes under the territorial cooperation objective or under the European Agricultural Fund for Rural Development and the European Maritime and Fisheries Fund (Dudic et al., 2020).

With regard to the use of the European Union's structural, investment and regional policy instruments, we consider it necessary to mention that, despite the obligation of each Member State 
to contribute to the common budget, Slovakia still has the status of 'net beneficiary', i.e. the funds drawn from European funds exceed our membership contributions. In the current period, the Slovak Republic manages, implements and controls around EUR 15.34 billion. EUR from European Union budget resources. But it is only a question of how long we will still benefit from the Union's structural and investment policy. It is therefore essential that European funds be used as efficiently as possible.

\section{Theoretical background}

Since the very beginning, the European Union (EU) aimed at promoting a greater convergence of the economic growth between the member countries. This is why, during time, several investment policy tools have been developer (Diaconu and Maxim, 2019). ESIF are very important for less-developed regions since these funds should help in reducing disparities among regions (Beugelsdijk and Eijffinger, 2005). These interventions are usually motivated by the widespread concern that economic development generates unequal living conditions across regions (Blouri and Ehrlich, 2020).

The European Structural and Investment Funds (ESIF) make it possible to create the right momentum and boost investment (Zacek et al., 2021). They represent real EU support for the structured development of national economies according to the performance goals. Also the fact that elements of policy have consequences for a country's competitiveness should not be overlooked (Postula and Raczkowski, 2020).

However, the Union's structural and investment policy cannot be seen in black and white. Several political, economic, social and regional aspects need to be taken into account. Subsidies can lead to a welfare loss for the EU as a whole and that they definitely lead to welfare losses in the rest of the world, from which investments flow to the supported EU regions (Korzhenevych and Brocker, 2020). Some studies indicate that ESIF funding has not supported income growth in EU regions (Breidenbachet al., 2019).

The sustainability of public spending is really important for Slovakia and every EU Member State. It is gaining even greater momentum in the ongoing coronavirus pandemic (European Commission, 2020). The political situation and the relations between various layers of governance influence the allocation and implementation proces (Bouvet and Dall'Erba, 2010). The accessibility of EU funds is also conditioned by the administrative bureaucracy. The role of human 
capital potential was thus confirmed in realizing the basic goals of the EU cohesion policy (Dubel and Pawłowska, 2020). Some studies demonstrated that in case the national institutional apparatus assigned to the European structural funds' management is bureaucratic, the chance for a deficient management is higher, and hence the sustainable economic growth is negatively affected (Antohi et al., 2020). Countries aimed at the effective and flexible implementation of EU funds are more successful than countries whose flexibility is limited by policy makers.

We can only understand the effects of spending on support for the EU when examining how transfers are spent (Dellmuth and Chalmers, 2018). EU funds mitigate Euroscepticism only where they are coupled with tangible improvements (Crescenzi et al., 2020). Researching the specialist literature, we came across constant concerns for allocation of EU funds, the absorption capacity of the beneficiaries or inefficient and inflexible management and implementation by national authorities. These are factors that would implicitly increase the chances of implementing cohesion policy.

\section{Objective and methodology}

The main objective of the paper is to evaluate Slovakia's state of preparedness for the next programming period 2021 - 2027 and propose recommendations and measures to improve the management, implementation and control of the European Structural and Investment Funds. The sub-objectives of the paper are:

- evaluate the state and evolution of the contracting of commitments and absorption of funds as the financial indicators for the ongoing programming period 2014-2020 and compare it with the completed 2007-2013 programming period;

- propose recommendations and actions for the next programming period 2021-2027 focusing on the strategic level of the management and control system of the European Structural and Investment Funds.

The research was carried out in relation to the completed programming period 2007-2013 and the ongoing programming period 2014-2020. We did not reflect our examination of the first programming period for Slovakia, which we used after we joined the European Union with a shortened duration in 2004-2006. This decision was due not only to differences in duration or in management and control systems, but in particular to relatively little experience with the 
implementation of European funds by the responsible national authorities, which could lead to a distortion of the conclusions of our research.

Based on the knowledge of the area of selected issues examined and our theoretical and practical knowledge so far in the field of implementation and auditing of international resources, we have identified the following research question: Is there an increase in the share of the contracting of commitments and the absorption of European funds under the 2014-2020 programming period compared to the 2007-2013 programming period?' The data source for this comparative analysis was publicly available data from the responsible authorities for the period in which they carried out the tasks of the Central Coordination Body, i.e. the Ministry of Transport, Construction and Regional Development of the Slovak Republic (2007-2013), the Office of the Government of the Slovak Republic (2013-2016), the Office of the Deputy Prime Minister of the Slovak Republic for Investment and Informatisation (2017-2019) and the Ministry of Investments, Regional Development and Informatization of the Slovak Republic (2020).

Several scientific methods of knowledge have been used in the explorationand development of the paper. We apply the method of analysis primarily to examine the state of the implementation of the European Funds in the Slovak republic. The synthesis will allow us to combine partial information into a single unit. We apply the deduction method to clarify the system of management, implementation and control of EU funds. We use the comparative method to compare the state and development of the financial indicators, operational programmes and programming periods as well. In view of the fact that little attention is paid to the issues examined in the field of science and research, the practical experience of the author in carrying out government audits of international resources, as well as in the implementation of the European Structural and Investment Funds in the Slovak Republic, has been widely used.

\section{Results and Discussion}

Building on the objectives set and the research issue outlined in the previous part of the paper, our examination focused on the core performance indicators of the OPs. The degree of contracting of commitments and absorption of European Structural and Investment Funds are financial indicators to assess the state of implementation of the operational programme as well as the entire programming period.

With regard to the " $n+3$ " rule, rapid and efficientabsorptionis essential for the successful 
implementation of the operational programme. These indicators have also increased in the 20142020 programming period following the new competence of the Deputy Prime Minister's Office for Investment and Informatisation as the Central Coordinating Body consisting of the crisis management of the operational programme if the OP does not achieve the implementation of the binding plan by 31 December year " $n$ " to at least $80 \%$ (Central Coordination Body, 2017).

Evaluation of the state of implementation of the European Structural and Investment Funds Currently, for the third programming period, the Slovak Republic manages, implements and controls the European Structural and Investment Funds for a total amount of approximately EUR 15.34 billion. The table below shows the breakdown by Fund of the total funds allocated to the Slovak Republic in the second completed and third ongoing programming periods.

Table 1: Comparison of the allocation of the European Structural and Investment Funds to the Slovak Republic in the 2007-2013 and 2014-2020 programming periods (EUR billion)

\begin{tabular}{|c|c|c|c|c|}
\hline \multirow[b]{2}{*}{ Fund } & \multicolumn{2}{|c|}{ Programming period } & \multicolumn{2}{|c|}{ Difference } \\
\hline & $\begin{array}{l}2007- \\
2013 \\
\text { (billion) } \\
\text { EURO) }\end{array}$ & $\begin{array}{l}2014- \\
2020 \\
\text { (billion) } \\
\text { EURO) }\end{array}$ & $\begin{array}{l}\text { billion } \\
\text { EURO }\end{array}$ & $\%$ \\
\hline European Regional Development Fund & 6,100 & 7,350 & $+1,25$ & $+20,49$ \\
\hline Cohesion Fund & 3,899 & 4,168 & $+0,269$ & $+6,90$ \\
\hline European Social Fund & 1,484 & 2,045 & $+0,561$ & $+37,80$ \\
\hline $\begin{array}{l}* \text { Youth Employment Initiative } \quad(2014-2020 \\
\text { programming period only) }\end{array}$ & - & 0,207 & $+0,207$ & - \\
\hline European Agricultural Fund for Rural Development & 1,997 & 1,560 & $-0,437$ & $-21,88$ \\
\hline European Maritime and Fisheries Fund & 0,013 & 0,013 & 0 & 0 \\
\hline TOTAL & 13,49 & 15,34 & $+1,85$ & $+13,71$ \\
\hline
\end{tabular}

Data source: Central Coordinating Body, own processing

In the 2014-2020 programming period, the total allocation increased by around EUR 1.85 billion compared to the previous programming period, which represents an increase of $13,71 \%$. 
The most significant increase was recorded under the European Regional Development Fund and the European Social Fund, which is also complemented by the Youth Employment Initiative (YEI) in the current period.

\section{Programming period 2007-2013}

The timeframe for the eligibility of expenditure was set in such a way that expenditure incurred between 01 January 2007 and 31 December 2015 was considered eligible (Stancikova, 2016). The start of the programming period was accompanied by a slow pace of implementation of almost all operational programmes. Managing authorities had problems not only with low absorption but also with low contracting of their commitments. Based on our own experience in implementing and auditing international resources, we know that the area of public procurement has been identified as a source of problems in several OPs. Difficult and often lengthy public procurement procedures, incorrect application of public procurement principles, rules and procedures by contracting authorities, but also lack of control by managing authorities and intermediate bodies. All this caused not only time losses, but above all financial corrections imposed by national audit bodies as well as by the European Commission. Other problems affecting the implementation and absorption of funds varied and varied depending on the OP.

Also in view of the slow progress in contracting commitments and, in particular, the absorption of funds, as well as the other problems mentioned above, the Slovak Republic has not managed to draw on all the funds allocated. An analysis of the available data as of 31 March 2018, i.e. after the completion and settlement of the entire programming period, showed that the absorption of all operational programmes implemented by European funds was $96.87 \%$ (Central Coordination Body, 2019).

The Transport Operational Programme (99,92\%) can be identified as the most successful in terms of the absorption rate of the allocation. The implementation of the Operational Programmes Competitiveness and Economic Growth, Bratislava Region or INTERACT II was also very good. Conversely, the operational programmes Fisheries (80.31 \%) and Health (87.43 $\%)$ were the least successful in terms of absorption. With regard to the Operational Programme Health, we consider it necessary to add that its implementation has been relatively good until the implementation of the European Commission Mission No 2013//SK/REGIO/C4/1221/1 in April 2013. The Commission identified a number of serious breaches of public procurement principles, 
rules and procedures, for which it granted corrections of $25 \%$ and $100 \%$ respectively of the expenditure of the procurements in question.

\section{Programming period 2014-2020}

In terms of time frame, expenditure incurred or incurred in the period from 01 January 2014 to 31 December 2023 is eligible. To this baseline expected pace and structure of implementation alternative policy scenarios with respect to the time allocation and regional allocation were defined (Radvansky, M. et al., 2016). Despite relatively rich past experience, the responsible national authorities have not learnt. As in the previous programming period, the start and progress of the 2014-2020 programming period was accompanied by a weak start-up curve and a slow pace of implementation.

As regards to the compliance with the " $n+3$ " rule for the sake of completeness, we would point out a 'decommitment', i.e. a permanent loss of funds. It's a new rule in current programming period. Decommitment has already occurred repeatedly under the Operational Programmes Research and Innovation or Fisheries (Horvathova and Cajkova, 2018). Slovakia lost a total of 108,42 million euro per EU resource in 2017 and 2018 alone under the Operational Programme Research and Innovation, the highest decommitment for all implemented programmes. Total allocation of this programme was more than 2,1 billion euro per EU resourse and the absorption rate was $12,07 \%$ on 30 September 2019. As a follow-up, the Central Coordination Body proposed to merge the Operational Programme Research and Innovation with the Operational Programme Integrated Infrastructure, in order to improve the absorption of European research and innovation funds and create scope for eliminating their loss, without changing their intended use. Both the Slovak Government and the European Commission approved the proposal and the operational programmes were merged in December 2019.

We are currently in the second half of the programming period, but this is not matched by the implementation indicators. In order to better illustrate the results of the analysis, the following graphical representations are provided. 
Figure 1: Contracting and Deployment status in relation to the total allocation under the operational programmes of the 2014-2020 programming period as at 30 September $2020^{1}$

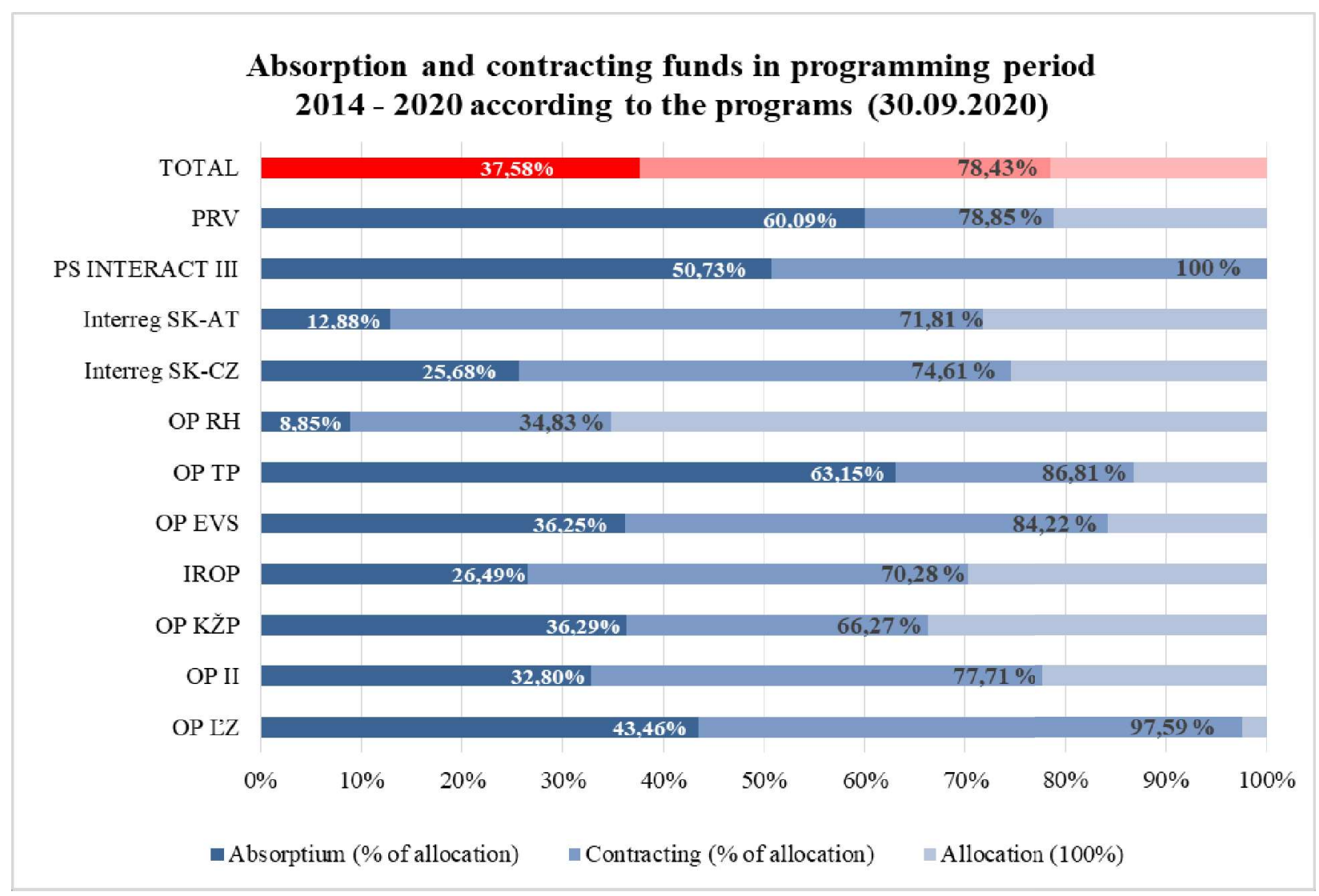

Data source: Central Coordinating Body, own processing

As shown in Figure 1, not only the absorption rate of funds but also the rate of contracting of commitments is low. Overall, this was $78,43 \%$ on 30 September $2020(+15,64 \%$ per year).

\footnotetext{
${ }^{1}$ Legend: PRV (Rural Development Programme), PS INTERACT III (Cooperation Programme INTERACT III), Interreg SK-AT (Cross-border Cooperation Programme Slovakia-Austria), Interreg SK-CZ (Cross-border Cooperation Programme Slovakia-Czech Republic), OP RH (Operational Programme Fisheries), OP TP (Operational Programme Technical Assistance), OP EVS (Operational Programme Effective Public Administration), IROP (Integrated Regional Operational Programme), OK KŽP (Operational Programme Quality of Environment), OP II (Operational Programme Integrated Infrastructure), OP LZ (Operational Programme Human Resources)
} 
Only INTERACT III, which is the second smallest programme in terms of size of allocation, is fully contracted by INTERACT III. The Operational Programme 'Fisheries' was particularly at risk in terms of contracting. Contracting rate was $34,83 \%$, but the year-on-year growth $(+15,84$ $\%)$ was caused by a decommissioning of 1 million euro ( $8,8 \%$ of allocation).

The overall implementation on 30 September 2020 was $37,58 \%(+10,18 \%$ per year), which can be assessed as insufficient and irresponsible by the national authorities. In this context, neither the " $\mathrm{n}+3$ " rule and the threat of part of the financial commitments from the European Funds seem to be a sufficient incentive for the smooth and efficient implementation of European funds. The status of all OPs can be assessed as unfavourable, only 2 of them reached a $50 \%$ absorption rate at 30 September 2020. The Rural Development Programme (60,09 \%) and the Operational Programme Technical Assistance (63,15\%) have the most spent funds. By contrast, both cross-border cooperation programmes Interreg SK-AT (12,88 \%) and Interreg SK-CZ (25,68 $\%)$ and the Fisheries Operational Programme (8,85\%) have the least absorbed funds from the total allocation. However, the Integrated Regional Operational Programme (26,49 \%) can be identified as particularly at risk, especially in view of the multiplicatively higher overall allocation compared to the previously mentioned (smaller) operational programmes.

\section{Comparative analysis of indicators on the state of implementation}

Following the identified research question, we focused on whether there had been an improvement in the observed indicators for the 2014-2020 programming period compared to the previous programming period. We assumed that the learning curve would be better and the pace of contracting and absorption of funds would be faster. This assumption was mainly based on the experience of the national authorities with the implementation of international resources, but we also took into account the threat of losing part of the commitments if they were not used under the established " $n+3$ " rule applied in the current programming period. In order to evaluate the research issue identified, we compared the contracting of commitments and the absorption of funds for the same section, namely the first 7 years of the programming period. For greater clarity, we have shown the results of the comparison graphically. 
Figure 2: Evolution of the contracting of commitments for the 2007-2013 and 2014-2020 programming periods

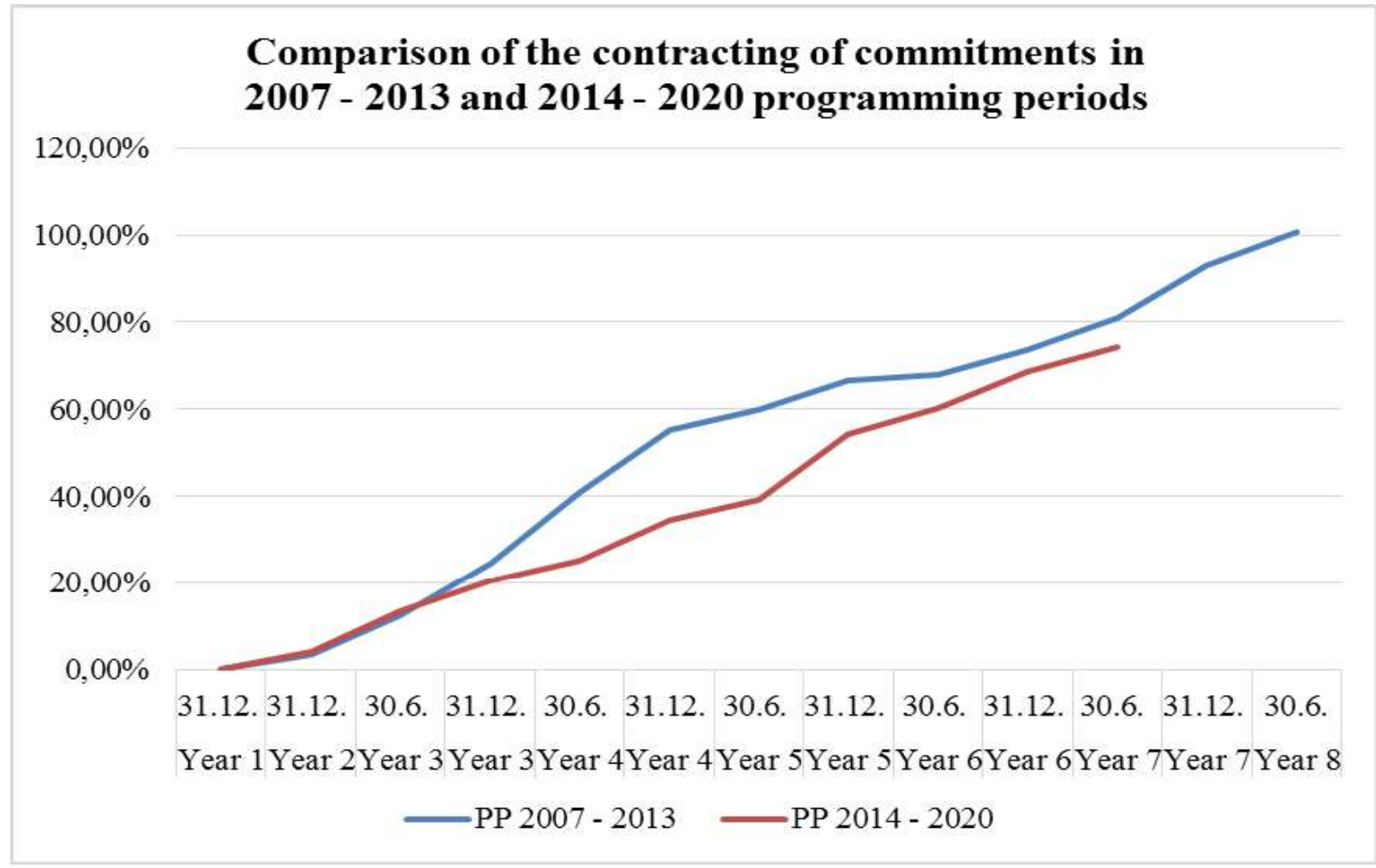

Data source: Ministry of Transport, Construction and Regional Development of the Slovak Republic (data for the period 2007-2013), Government Office of the Slovak Republic (data for the period 2013-2016), Office of the Deputy Prime Minister of the Slovak Republic for investment and Informatization (data for the period 2017-2019,) Ministry of Investments, Regional Development and Informatization of the Slovak Republic (2020), own processing

As shown in Figure 2, the curve was weak in both programming periods and almost no funds were contracted in the first two years. In addition, we observed that in the third to fifth years of implementation of the current programming period, the pace of contracting was even slower than in the previous period. At the same time, the low rate of contracting of commitments entails high pressure on the submission of payment claims and spending under existing projects, which may in turn be accompanied by a higher error rate for the operational programme after government audits have been carried out. 
Figure 3: Evolution of the absorption of funds for the 2007-2013 and 2014-2020 programming periods

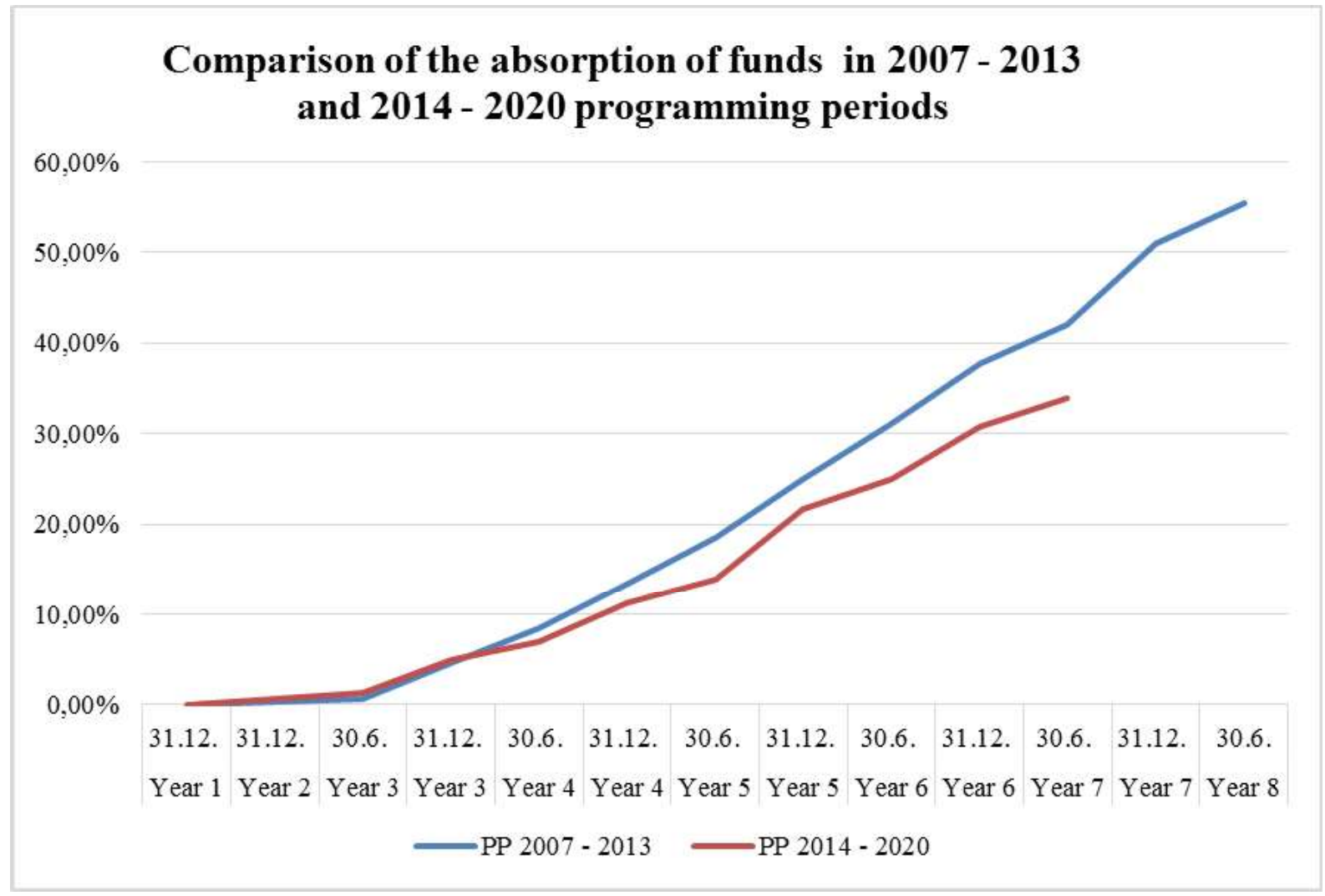

Data source: Ministry of Transport, Construction and Regional Development of the Slovak Republic (data for the period 2007-2013), Government Office of the Slovak Republic (data for the period 2013-2016), Office of the Deputy Prime Minister of the Slovak Republic for investment and Informatization (data for the period 2017-2019), Ministry of Investments, Regional Development and Informatization of the Slovak Republic (2020), own processing

Like the pace of contracting of commitments, the absorption rate of funds was weak in both programming periods. At the end of the third year of the current programming period, i.e. 31 December 2016, the absorption rate was $5 \%$. Despite all the implemented measures mentioned in the previous parts of the paper, including the merger of the Operational Programme Research and Innovation with the Operational Programme Integrated Infrastructure, the absorption rate of funds is not even at the level of the previous programming period. As at 30 September 2020, only 37.58 $\%$ of the total fund allocation had been spent, and not only the remaining approximately EUR 10 
billion would have to be spent in the coming years 2021-2023. But also to prepare and start implementing the new programming period 2021-2027.

Proposals for recommendations and measures for the 2021-2027 programming period

In 2019, it was particularly possible at European level to see intensive preparations for the 2021-2027 Multiannual Financial Framework. The Commission has proposed a long-term budget equivalent to $1.114 \%$ of the gross national income of the EU27 (European Commission, 2019). In addition to increasing the focus on certain areas or changes in the distribution of funds between sectors, the European Commission is also proposing the application of the " $\mathrm{n}+2$ " rule, which would put even greater pressure on contracting commitments and absorption of funds than hitherto.

In view of the above, we consider that the effectiveness of measures aimed at improving the level of contracting of commitments and absorption of funds will be one of the main prerequisites for its overall success in the 2021-2027 programming period. In our view, it will not be easy to combine implementation and closure under the 2014-2020 programming period with the preparation and start of the implementation of the next programming period with the current state of administrative capacity in the field of European funds (the so-called 'Euro-officials'). Against this background, we propose to adopt a set of optimisation measures, both at strategic level and subsequently at programme level, which will improve contracting and absorption under the new operational programmes.

At strategic level, we consider particularly important measures aimed at:

- eliminating or minimising policy impacts on the management of the European Structural and Investment Funds;

- timely and rigorous preparation of the programming period;

- timely development of strategic documentation with the participation of other responsible national authorities and socio-economic partners;

- changes in the control system for public procurement/procurement.

As mentioned above, negotiations on the shape of the multiannual financial framework are still ongoing at European Union level, making it difficult to prepare the programming period at national level. In this context, the only solution is to eliminate political influences and leave 
decision-making to expert authorities. Although this is a very unpopular measure, it is only in this way that the risks associated with political change can be avoided. A concrete solution could also be the creation of an institution specialised exclusively in the management and implementation of the European Structural and Investment Funds. Following the current change in the political environment, the creation of such a ministry can be expected in the coming period, but this will not eliminate political influences. We therefore recommend the establishment of a central government body, e.g. in the form of a National Agency. Similar centralisation can be found in other countries of the European Union, e.g. Slovenia, which implements all thematic areas and investment priorities of the Investment for growth and jobs goal under one programme.

We assess Slovakia's state of preparedness for the new programming period as insufficient. The central coordinating body had sufficient time to prepare specific documents and measures. To date, however, it has not presented a concrete vision on the management of operational programmes, except for efforts to reduce the number of operational programmes. We therefore consider the setting of uniform rules and the adoption of concrete measures to eliminate the risk of repetition of errors from previous periods as one of the important recommendations. As part of our analysis of the state of implementation of the 2007-2013 and 2014-2020 programming periods, we demonstrated in particular the slow contracting and absorption of funds linked to a weak learning curve. The central coordinating body must be prepared for the pressure imposed by the introduction of the " $\mathrm{n}+2$ " rule and, at the same time, be a partner for future managing authorities. Only a responsible approach to the preparation of the programming period can eliminate future risks associated with the implementation of operational programmes. The central coordinating body should benefit not only from historical experience at national level but also from experience in managing and implementing European funds in other Member States of the European Union.

In addition to the preparation of the Partnership Agreement for the next period, the Central Coordination Body should also focus more on the preparation of management documentation at strategic level, i.e. in particular the management system and related methodological instructions and templates. In view of the fact that, for the European Commission and its services, the partners are mainly the bodies defined in the regulations and the final responsibility for the management of the operational programme lies with the managing authority, we propose to consider the binding nature of the management system. We consider that the Central Coordination Body should provide assistance and support to managing authorities, in particular in the methodological field. The 
specific specificities of operational programmes are only known to the managing authorities specifically responsible, which should be able to set up and adapt the management and control system to their own circumstances. The sufficiency of the set-up of the management and control system is subject to system audits. The competence to determine the set-up of the system under the terms of a specific operational programme should lie with the Central Coordination Body only in the case of crisis management, when it participates in the management of the operational programme.

In addition to the changes in the binding nature of the management documentation at strategic level, we would recommend that the Central Coordination Body already hold intensive working meetings with representatives of the current managing authorities, the certifying authority, the audit authority and other bodies, in order to reach consensus on the basic rules for the implementation of operational programmes. One of the cross-cutting areas is e.g. setting deadlines for action by managing authorities/intermediate bodies. We generally appreciate the efforts to reduce time limits and strengthen rights for beneficiaries, but should not serve as a "block" for the responsible authorities, but should reflect the objective needs of these authorities to carry out all the necessary actions with their available capacities. Therefore, there is a need to reach more consensus on how to shape them, especially when the management system is binding in the next programming period. Last but not least, the Central Coordination Body should support the European Commission's efforts to harmonise the rules within the European Structural and Investment Funds, not only in relation to the rules on eligibility of expenditure. Harmonisation of rules can greatly help simplify the system, not only for managing authorities but especially for beneficiaries.

Our previous research confirmed that public procurement is the most risky area of implementation of the European Structural and Investment Funds in terms of weaknesses and irregularities with financial impact, we consider it necessary to make changes in this area in the next programming period. Several authors still perceive public procurement as a problematic aspect of drawing structural funds, e.g. Kováčiková (2018). Lower savings in public procurements co-financed by EU funds are confirmed by studies by other authors, for example Dzupka et al. (2020). In the area of public procurement control, we propose to include the Public Procurement Office as the central government body in the field of public procurement in the management and control system of the European Structural and Investment Funds and other European resources, 
with its full responsibility in the field. We believe that the involvement of the Public Procurement Office in the management and control system of the European Structural and Investment Funds, with its full responsibility, will mean not only a more professional implementation of controls for a given area of implementation, but in particular the elimination of the current dualism of performing controls by both the managing authority/intermediate body and the Public Procurement Office. This should improve the overall performance of public procurement, in particular in the field of first-level checks, transparency and its overall professionalisation. We also believe that this will lead to time savings and faster implementation of the project by the beneficiaries.

In order to eliminate possible risks related to low contracting and absorption of funds, we believe that measures need to be taken and applied consistently also at the level of approved operational programmes. At programme level, we recommend in particular:

- simplification of rules and procedures targeting applicants and beneficiaries, including greater use of simplified cost options;

- greater use of financial instruments;

- performing a performance-oriented staff and organisational audit.

\section{Conclusion}

Further to the objectives set, we focused our paper on the core performance indicators of the operational programmes implemented in Slovakia, namely the contracting of commitments and the absorption of funds. These indicators serve not only to assess the state of implementation of a particular operational programme, but also to assess the entire programming period. In the context of the " $n+3 "$ rule, which applies in the current programming period, coupled with the threat of decommitment or crisis management by the Central Coordination Body, swift and efficient contracting and absorption of funds is essential for the successful implementation of the operational programme.

The first programming period used by the Slovak Republic during its entire duration was the 2007-2013 programming period. In relation to the indicators monitored, this period was accompanied by a weak start-up curve and a slow pace of implementation across all operational programmes, to which, inter alia, public procurement issues have contributed significantly. Difficult and often lengthy public procurement procedures, incorrect application of principles, 
rules and procedures by contracting authorities, but also lack of control by managing authorities and intermediate bodies. All this caused not only time losses, but above all financial corrections imposed by national audit bodies as well as by the European Commission. The Slovak Republic has therefore not managed to spend all allocated funds.

Building on the experience that the Slovak Republic had before the start of the 2014-2020 programming period, we assumed that the contracting and absorption rates of the funds, as well as their start-up curves, would be better. In relation to the research question identified as to whether there was an increase in the share of the contracting of commitments and the absorption of European funds under the 2014-2020 programming period compared to the 2007-2013 programming period, we found that the results for both indicators examined wereworsein the 20142020 programming period than in the previous period. At the same time, the lowrate of contracting of commitments entails high pressure on the submission of payment claims and spending under existing projects, which may in turn be accompanied by a higher error rate for the operational programme after government audits have been carried out. As at 30 September 2020, only 37.58 $\%$ of the total fund allocation had been spent, and not only the remaining approximately EUR 10 billion would have to be spent in the coming years 2021 - 2023. But also to prepare and start implementing the new programming period 2021-2027.

The added value of our research are several findings and recommendations. Based on the above findings, as well as on the changes proposed by the European Commission, including the application of the " $\mathrm{n}+2$ " rule, we believe that the effectiveness of measures aimed at improving the rate of contracting of commitments and absorption of funds will be one of the main prerequisites for its overall success in the 2021-2027 programming period. In our view, it will not be easy to combine the implementation and closure of the 2014-2020 programming period with the preparation and start of the implementation of the next programming period with the current state of administrative capacity in the field of European funds. Against this background, in the second part of our paper, we have proposed a core set of optimisation measures, both at strategic level and subsequently at programme level.

At strategic level, we proposed measures aimed at eliminating policy impacts on the management of the European Structural and Investment Funds, timely and rigorous preparation of the programming period and strategic documentation, or changes to the public procurement control system. At programme level, we also delivered a set of optimisation measures aimed at ensuring 
the efficient management and control of European funds. In our view, priority should be given to measures to simplify rules and procedures, including greater use of simplified cost options or greater use of financial instruments. In addition to actions targeting applicants and beneficiaries, we also recommended that the National Audit Authority perform performance-oriented staff and organisational audits within all responsible authorities at programme level.

At present, it is not possible to say with certainty what changes the future programming period 2021-2027 will bring. The ability of national authorities to respond flexibly to these changes, both at strategic and programme level, will be all the more crucial. The Slovak Republic has experienced the implementation, control and audit of foreign aid programmes since 2000, which is sufficient time to use these results to improve the established processes and systems for the future.

\section{References}

1. Antohi, V. M., Zlati, M. L., Ionescu, R. V., Rusu, R. and Constantin, A. (2020). Attracting European funds in the Romanian economy and leverage points for securing their sustainable management: A critical auditing analysis, Sustainability, 12 (13), article no. 5458.

2. Beugelsdijk, M. and Eijffinger, S. C. W. (2050). The effectiveness of structural policy in the European Union: An empirical analysis for the EU-15 in 1995-2001', 2005, Journal of common market studies, 43 (1), pp. 37-51.

3. Blouri, Y. and Ehrlich, M. V. (2020). On the optimal design of place-based policies: A structural evaluation of EU regional transfers. Journal of International Economics, 125, article no. 103319.

4. Bouvet, F. and Dall'Erba, S. (2010). European Regional Structural Funds: How Large is the Influence of Politics on the Allocation Process?. JCMS-Journal of common market studies, 48 (3), pp. 501-528.

5. Breidenbach, P., Mitze, T. and Schmidt, C. M. (2019). EU Regional Policy and the Neighbour's Curse: Analyzing the Income Convergence Effects of ESIF Funding in the Presence of Spatial Spillovers. JCMS-Journal of common market studies, 57 (2), pp. 388405. 
6. Central Coordinating Body. (2019). Information on the state of implementation of the European Structural and Investment Funds in the 2014-2020 programming period. Bratislava: Office of the Deputy Prime Minister of the Slovak Republic for Investment and Informatisation.

7. Central Coordinating Body. (2017). Methodological Instruction No 33. Bratislava: Office of the Deputy Prime Minister of the Slovak Republic for Investment and Informatisation

8. Crescenzi, R., Di Cataldo, M. and Giua, M. (2020). It's not about the money. EU funds, local opportunities, and Euroscepticism. Regional Science and Urban Economics, 84, article no. 103556.

9. Dellmuth, L. M. and Chalmers, A. W. (2018). All spending is not equal: European Union public spending, policy feedback and citizens' support for the EU. European journal of political research, 57 (1), pp. 3-23.

10. Diaconu, L. and Maxim, A. (2019). EU structural funds and the economic growth of Romania. European Union financial regulation and administrative area (EUFIRE 2019), pp. 675-685.

11. Dubel, P. and Pawłowska, A. (2020). The beneficiaries of training co-financed by the ESF and their employability market orientation in creating labour market competitiveness', 2020, Sustainability, 12 (22), article no. 9712, pp. 1-21.

12. Dudic, B., Dudic, Z., Pejanovic, R., Skataric, G., Saxunova, D. and Peracek, T. (2020). The rural policy of Slovakia after joining the EU, Agriculture and Forestry, 66 (3), pp. 33-51. doi: 10.17707/AgricultForest.66.3.04

13. Mura, L. and Vlacseková, D. (2018). Motivation of public employees: case study of Slovak teaching and professional staff. Administratie si Management Public, (31), pp. 67-80, doi: 10.24818/amp/2018.31-05

14. Džupka, P., Kubák, M. and Nemec, P. (2020). Sustainable public procurement in central european countries. Can it also bring savings. Sustainability, 12 (21), article no. 9241, pp. $1-13$.

15. European Commission. (2019). Communication from the commission to the European parliament, the European council and the Council: Time to decide on the Union's financial 
framework for 2021-2027. [Online] at https://ec.europa.eu/commission/sites/betapolitical/files/communication-euco-mff-oct2019_en.pdf.

16. European Commission (2014). Priorities for 2014-2020. [Online] at https://ec.europa.eu/regional_policy/sk/policy/how/priorities.

17. European Commission (2020). Recovery Plan for Europe. [Online]. Available at: https://ec.europa.eu/info/livework-travel-eu/health/coronavirus-response/recovery-planeurope_en.

18. Horvathova, Z. and Cajkova, A. (2018), Social and economic aspects of the EU's education policy, Integration of Education, 22 (3), pp. 412-425.

19. Korzhenevych, A. and Brocker, J. (2020). Investment subsidies and regional welfare: a dynamic framework and its application to the European regional policy. Regional studies, 54 (9), pp. 1262.1274.

20. Kováčiková, H. (2018). Verejné obstarávanie ako problematický aspekt čerpania štrukturálnych fondov. In Právo fondov EÚ v teórii a praxi, Bratislava: Úrad podpredsedu vlády SR pre investície a informatizáciu, pp. 76-85.

21. Kubincová, S., Pekár, B., Píry, M. and Kubincová, T. (2018). Právo európskych štrukturálnych a investičných fondov. Banská Bystrica: Belianum,

22. Peráček, T. (2020). The perspectives of European society and the European cooperative as a form of entrepreneurship in the context of the impact of European economic policy. Online Journal Modelling the New Europe, (34), pp. 38-56. doi: 10.24193/OJMNE.2020.34.02

23. Postula, M. and Raczkowski, K. (2020). The impact of public finance management on sustainable development and competitiveness in EU member states. Journal of Competitiveness, 12 (1), pp. 125-144.

24. Radvansky, M., Miklosovic, T. and Lichner, I. (2016). Modeling ex-ante effects of alternative regional cohesion policy in 2014-2020 period on national level - case of Slovakia. Proceedings of the international conference: Quantitative methods in economics: Multiple criteria decision making XVIII, pp. 316-321.

25. European Parliament and of the Council (2013). Regulation (EU) No 1303/2013 of the European Parliament and of the Council of 17 December 2013 laying down common 
provisions on the European Regional Development Fund, the European Social Fund, the Cohesion Fund, the European Agricultural Fund for Rural Development and the European Maritime and Fisheries Fund and laying down general provisions on the European Regional Development Fund, the European Social Fund, the Cohesion Fund and the European Maritime and Fisheries Fund and repealing Council Regulation (EC) No $1083 / 2006$.

26. Stancikova, M. (2016). Practical Aspects of EU Project and Grant Management in Programming Period. Proceedings of the 3rd international konference on european integration 2016 (ICEI 2016), pp. 898-907.

27. Zacek, J., Hruza, F. and Volcik, S. (2021). The Impact of EU Funds on Regional Economic Growth of the Czech Republic. Finance a uver-Czech journal of economics and finance, 69 (1), pp. 76-94. 